\title{
PERENCANAAN KEPERAWATAN BAGIAN ASUHAN KEPERAWATAN
}

\author{
Sophia Lumbanbatu
}

\author{
Sophialumbanbatu@gmail.com
}

\begin{abstract}
LATAR BELAKANG
Perencanaan keperawatan atau biasa disebut intervensi keperawatan merupakan bagian dari proses keperawatan yaitu tahap ketiga. Setelah mengetahui diagnose keperawatan yang tepat untuk pasien, selanjutnya perawat menentukan dan memepersiapkan perencanaan keperawatan untuk diiimplementasikan ketika memberi asuhan keperawatan. Perencanaan keperawatan yang dipersipakan oleh perawat tentunya harus berhbungan dengan kondisi pasien berdasarkan pengkajian dan diagnose keperawatan.
\end{abstract}

Hal penting yang perlu diketahui terkait perencanaan keperawatan ini perawat perlu menentukan prioritas, menulis tujuan, dan merencanakan tindakan keperawatan tang akan dilakukan. Pada tahap menentukan prioritas perawat menentukaan masalah pasien yang terlebih dahulu diatasi. Diantara diagnosa keperawatan yang sudah ditentukan perawat harus bisa memprioritaskan hal yang terlebih dahulu dilakukan segera.

Pada tahap menuliskan tujuan, perawat menuliskan hasil yang perawat harapkan agar tercapai. Tujuan keperawatan yang jelas akan menunjukkan hasil dari tindakan keperawatan. Pernyataan tujuan harus merupakann perilaku pasien yang memeperlihatkan berkuragnya masalah yang dialami pasien. Tujuan juga harus realistis dan sejlaan dan menyokong atau membantu perawatan lain yang diterima pasien.

Selanjutnya yaitu rencana tindakan keperawatan yang merupakan tindakan yang 
direncanakan perawat untuk dilakukan pada saat pemberian asuhan keperawatan dlaam rangka menolong pasien untuk mencapai tujuan. Tindakan keperawatan yang dipersiapkaan pasien tentunya harus aman dan sesuai kondisi pasien, sejalan dengan terapi kesehatan atau tindakan pengobatan lainnya yang diterima pasien. Dan yang paling penting rencana keperawatn didasari pada prisip dan pengetahuan perawat dan juga pengalamannya.

Perenacanaan keperawatan sangat diperlukan dlaam pemberian asuhan keperawatan. Ini dikarenakan dalam setiap tindakan yang akan dilakukan perawat sudah menyusun rencana keperawatan terlebih dahulu agar pada saat implementasi tidak salah. Perawat perlu menyiapkan hal ini untuk memberikan pelayanan yang baik bagi pasien.

Kata Kunci : Perencanaan, keperawatan, pelayanan, asuhan

\section{TUJUAN}

Perencanaan keperawatan memiliki peran penting dalam asuhan keperawatan, semakin baik perencanaan keperawatan yang dipersiapakan oleh perawat tentu perawat akan mampu memberikan asuhan ataupun pelayanan keperawatan yang tepat kepada pasien. Oleh karenaitu, perawat yang berfikir kritis harus bisa mempersiapkan rencana keperawatan yang tepat. Dalam setiap tindakan keperawatan perawat akan memberikan tindakan yang didasari pada rencana keperawatan yang sudah dipersiakan berdasarkan diagnosa dan pengkajian yang dilakukan terlebih dahulu.

\footnotetext{
METODE

Metode dalam pembuatan kajian tersebut yaitu literasi. Saya membaca dari berbagai referensi berupa buku dan jurnal. Melalui metode literature ini saya
} 
memahami dan mengidentikasi perencanaan keperawatan, bagaimana membuat prioritas masalah, membuat tujuan dan kriteria hasil, memutuskan perencanan keperawatan yang akan diimplementasikan.

\section{HASIL}

Berdasarkan hasil literature saya, bahwa perawat yang professional dalam memberikan asuhan tentu akan memepersiapkan terlebih dahulu perencanaan yang akan diimplementasikan. Semua tindakan pelayanan dilakukan berdasarkan proses keperawatan.

Pengetahuan dan motivasi perawat juga berpengaruh, salah satu literature saya menunjukkan bahwa perawat yang memiliki pengetahuan yang tinggi mengenai proses keperawtan termasuk intervensi keperawatan akan dapat memeberikan pelayanan yang semakin baik kepada pasien. Semakin tinggi pengetahuan perawat maka akan semakin baik pula perawat menerapkan perencanaan yang telah dipersiapkan. Ini menunjukkan pengetahuan yang dimiliki perawat menentukan ketepatan perawat dalam memberikan pelayanan.

Persepsi perawat juga memberikan pengaruh bahwa dengan persepsi negative tentu akan membuat asuhan yanga akan diberikan perawat akan kurang berhasil. Perawat perlu meyakinkan dirinya terhdaap tindakan yang akan dilakukan untuk memperoleh hasil yang baik. Ini akan bermanfaat untuk memeberikan pelayanan yang baik dan tepat pada pasien.

Dari banyak masalah yang dialami pasien, perawat perlu mengidentifikasi masalah yang terlebih dahulu diatasi. Intervensi yang dipersiapkan perawat tentunya lebih dari satu oleh karena itu perawat perlu membuat prioritas terlbih dahulu tindakan yang pertama kali dilakukan. 


\section{PEMBAHASAN}

Perencanaan keperawatan adalah pengembangan strategi desain untuk pencegahan, penguarangan juga mengatasi masalah-masalah yang telah diidentifikasi dalam diagnosis keperawatan. Perencanaan keperawatan dipersiapkan untuk menyelasikan masalah pada pasien. Perencanaan keperawatan menjadi dasar perawat dalam mengimplementasikan tindakan yang akan dilakukan.

Semua rencana keperawatan yang disusun merupakan pilihan yang rasional, benar - benar dapat mengatasi masalah pasien. Perawat harus mengimplementasikan semua perencanaan keperawatan yang sudah perawat persiapkan dengan selalu memantau kondisi pasien. Karena diagnosa keperawatan dapat berubah sesuai dengan rencana yang akan kita persiapkan sebelum melakukan tindakan keperawatan.

Bagian pertama dalam perencanaan keperawatan yaitu:

1.Menentukan prioritas masalah keperawatan

Pada tahap ini perawat akan menetukan masalah yang menjadi prioritas untuk diselesaikan terlebih dahulu. Bukan berarti perawat menyelesaikan satu masalah sampai selesai lalu menyelesaikan masalah berikutnya. Disini dalam menentukan prioritas perawat menentukannya berdasarkan bahwa masalah tersebut harus segera diatas karena akan berpengaruh terhdap maslah lain dan juga menjadi kondisi kesehatan pasien secara umum atau mempengaruhi status kesehatan umum pasien.

Dalam menentukan prioritas masalah dapat dilakukan sebagai berikut:

a. Prioritas pertama, yaitu masalah pasien yang mengancam kehidupan

b. Prioritas kedua, yaitu masalah pasien yang mengancam kesehatan

c. Prioritas ketiga, yaitu masalah yang berpengaruh terhadap perilaku manusia. Menurut Depkes RI tahun 1992 dapat dilakukan sebagai 
berikut: a. Prioritas pertama masalah aktual

b. Prioritas kedua masalah

potensial Menurut Hierarki

Maslow, yaitu: a. Fisiologu

b. Rasa aman dan nyaman

c. Cinta dan kasih sayang

d. Harga diri

e. Aktualisasi diri

\section{Menetapkan tujuan dan hasil}

Perawa perlu menetapkan tujuan yang berupa perubahan perilaku pasien yang diharapakan oleh perawat setelah diberikan tindakan keperawatan. Dalam menetapkan tujuan perawat perlu memperhatikan hal sepert:

a. Orang atau pasien yang akan mencapai tujuan atau diberi tindakan.

b. Perilaku yang diharapkan berubah dari pasien setelah diberikan tindakan dapat terlihat dari kepuasan pasien.

c. Kondisi yang menunjukkan kapan perilaku telah mencapai tujuan yang diharapkan.

Setelah menetapkan tujuan, lalu menetapkan kriteria hasil atau indicator keberhasila dari apa yang perawat harapkan meliputi pengetahuan (kognitif) yaitu perubahan pengetahuan pasien untuk menjadi lebih mengetahui yang konsep yang benar, perubahan status emosi (afektif) seperti marah, tidak kooperatif, keadaan menolak, perilaku (psikomotor) perubahan tindakan yang diperhatikan dengan nyata, perubahan fungsi tubuh yaitu respons tubuh terhadap keadaan patologis sehingga perawat berharap perubahan dari keadaan abnormal menjadi normal.

3. Merumuskan rencana tindakan keperawatan

Rencana tindakan keperawatan untuk membantu pasien dalam mencapai 
tujuan dan kriteria hasil yang diharapkan. Beberapa tipe rencana tindakan keperawatan yaitu:

a. Observasi, disini perawat akan mengobservasi terhadap kemajuan pasien dengan memantau perubahan pasien setelah diberikan intervensi. Diharapakan sesuai dengan tujuan dan kriteria yang diharapkan.

b. Terapeutik, tindakan yang dilakukan perawat untuk mengurangi, mencegah masalah. Perawat harus bisa dipilih tindakan yang paling sesuai dengan keadaan pasien.

c. Penyuluhan, tindakan ini berupa pendidikan kesehatan ini berguna untuk partisipasi pasien terhadap masalah kesehatan yang dialami pasien. Pasien bertanggungjawab untuk perawatan dini pasien. Tindakan pencegahan lebih baik daripada pengobatan. Dalam penyuluhan ini perawat juga mnenyesuaikan materi yang akan diberikan dengan kondisi pasien.

d. Kolaboratif, rencana kolaboratif disesuaikan dengan masalah yang terjadi. Masalah yang berhubungan dengan perubahan fungsi tubuh ataupun patologis memerlukan kolaboratif dengan tenaga kesehatan lainnya. Perawat melindungi pasien dari hal yang dapat merugikan dan memberikan saran yang bersifat konstruktif yang dapat menunjang kesembuhan pasien.

\section{Menetapkan rasional rencana tindakan keperawatan}

Rasional rencana tindakan keperawatan merupakan dasar ilmiah ditetapkannya rencana tindakan keperawatan. Rasional rencana tindakan keperawatan menerapkan berfikir kritis dalam pengambilan keputusan untuk menyelesaikan masalah pasien (Rohmah, 2016).

\section{PENUTUP}

Perencanaan keperawatan yang dipersiapkan oleh perawat harus berhubungan dengan kondisi pasien berdasarkan pengkajian dan diagnose keperawatan. Perencanaan keperawatan menjadi dasar perawat dalam mengimplementasikan 
tindakan yang akan dilakukan. Beberapa hal yang perlu diperhatikan dalam perenacanan keperawatan seperti menentukan prioritas masalah, menentukan tujuan dan kriteria hasil yang diharapkan, merumuskan rencana tindakan keperawatan dan rasional rencana tindakan keperawatan.

Perencanaan keperawatan merupak bagian dari proses keperawatan yang bermanfaat dalam pelayanan dan asuhan yang akan diberikan perawat kepada pasien.

\section{DAFTAR PUSTAKA}

Achmadi, L. D. (2015, Agustus). Gambaran Tingkat Pengetahuan Perawat dalam Penerapan Standar Asuhan Keperawatan di Ruang Rawat Inap Interna RSUP Datoe Bhinangkang. e-journal Keperawatan, 3.

Agustin, R. (2017). Optimalisasi Pelaksanaan Discharge Planning melelui Pengembangan Model Discharge Planning Terintegrasi Pelayanan Keperawatan. Jurnal Keperawatan Muhammadiyah, 2, 91-99.

Aini, D. N. (2018). Hubungan Kualitas Pelayanan Keperawatan dengan Tingkat Kepuasan Pasien Rawat Inap di RSUD DR. H. SOEWONDO KENDAL. Jurnal Ners Widya Husada Semarang , 2.

Allen, C. V. (1998). Memahami proses keperawatan dengan pendekatan latihan. (Setiawan, Ed.) Jakarta: EGC.

Azis, A. (2002). Pengantar Pendidikan Keperawatan. Jakarta.

Budiono, \& Parman, S. (2015). Konsep Dasar Keperawatan. Jakarta: Bumi Medika.

Carpenito, \& Juall, L. (1999). Rencana Asuhan \& Dokumentasi Keperawatan. (Y. Asih, Ed.) Jakarta: EGC.

Hasbi, F. H. (2012). Analisis Hubungan Persepsi Pasien tentang Mutu Pelayanan dengan Pemanfaatan Ulang Pelayanan Rawat Jalan Puskesmas Poncol Kota Semarang. Jurnal Kesehatan Masyarakat Universitas Diponegoro, 1.

Kasim, M., \& Abduroof, M. (2016, Mei). Peningakatan Kualitas Pelayanan dan Pendokumentasian Asuhan Keperawataqn dengan Metode TIM. Nurseline Journal, 1, 62-72. 
Monica, E., \& dkk. (2005). Pedoman Perawatan Pasien . Jakarta: EGC.

Nursalam. (2001). Proses \& Dokumentasi Keperawatan: Konsep dan Praktik. Jakarta:

Salemba Medika.

Purnamasari, L. D., \& Ropyanto, C. B. (2012). Evaluasi Pelaksanaan Perencanaan Pulang.

Jurnal Keperawatan Diponegoro, 1, 213-218.

Rohmah. (2016). Proses Keperawatan: Teori \& Aplikasi. Yogyakarta: Ar-Ruzz Media.

Simamora, R. H. (2008). PERAN MANAJER DALAM PEMBINAAN ETIKA

PERAWAT PELAKSANA DALAM PENINGKATAN KUALITAS PELAYANAN ASUHAN KEPERAWATAN. IKESMA, 2 (4).

Simamora, R. H. (2009). Dokumentasi Keperawatan. Jember: Jember University Press.

Simamora, R. H. (2010). Komunikasi dalam Keperawatan Jilid 1. Jember: Jember University Press.

Tucker, S. M. (1998). Standar Perawatan Pasien: Proses Keperawatan, diagnosis, dan evaluasi. (Y. Asih, Ed.) Jakarta: EGC. 